\title{
SIMULATION OF RECOGNITION METHOD OF DAMAGED PARTS OF HIGH-INTENSITY SPORTS INJURY IMAGES
}

\author{
SIMULAÇÃO DO MÉTODO DE RECONHECIMENTO DE PARTES DANIFICADASEM IMAGENS DE LESÕES \\ ESPORTIVAS DEALTA INTENSIDADE
}

\section{SIMULACIÓN DEL MÉTODO DE RECONOCIMIENTO DE PARTES DAÑADAS EN IMÁGENES DE LESIONES DEPORTIVASDE ALTA INTENSIDAD}

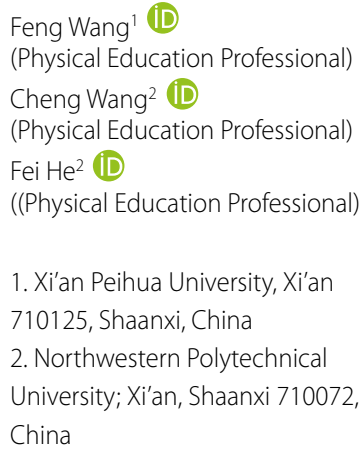

Correspondence:

Cheng Wang

Northwestern Polytechnical Universit, $X_{i}{ }^{\prime} a n$, Shaanxi 710072, China.wangcheng1715@yeah.net

\begin{abstract}
Introduction: When athletes are performing sports training, many movements are of high intensity, and that training is repetitive, resulting in wear and tear on some injured parts. Objective: Sports athletes can damage parts of the body in high - intensity exercise. During the processing, it is necessary to identify and analyze the damaged parts in the image. However, the current relevant methods have low accuracy and different problems of efficiency and quality. Methods: In this paper, a Fish Swarm Algorithm is proposed to identify high-intensity motion damage images. According to the combination of adaptive threshold and mathematical morphology, the contour of the damaged part of the image is extracted. Results: The above-mentioned method can improve the accuracy of identifying damaged parts of sports injury images, shorten the recognition time, and has certain feasibility in determining sports injury parts. Conclusions: This method can be widely used in high-intensity sports injuries. Level of evidence Il; Therapeutic studies - investigation of treatment results.
\end{abstract}

Keywords: Simulation; Recognition method; Damaged parts of high-intensity; Sports injury images.

\section{RESUMO}

Introdução: Quando os atletas estão realizando treinamento esportivo, muitos movimentos são de alta intensidade, e esse treinamento é repetitivo, resultando em desgaste de algumas partes lesionadas. Objetivo: Os atletas podem danificar partes do corpo em exercícios de alta intensidade. Durante o processamento, énecessário identificar e analisar as partes danificadas da imagem. No entanto, os métodos atuais relevantes têm baixa precisão e problemas de eficiência e qualidade diferentes. Métodos: Neste artigo, um algoritmo Fish Swarm éproposto para identificar imagens danificadas por movimento de alta intensidade. Com base na combinação de limiar adaptativo e morfologia matemática, o contorno da parte danificada da imagem é extraído. Resultados: O método acima mencionado pode melhorar a precisão da identificação das partes danificadas das imagens de lesões esportivas, encurtar o tempo de reconhecimento e tem alguma viabilidade para determinar as partes das lesões esportivas. Conclusões: este método pode ser amplamente utilizado em lesões esportivas de alta intensidade. Nível de evidência ll; Estudos terapêuticos- investigação dos resultados do tratamento.

Descritores: Simulação; Método de reconhecimento; Partes danificadas de alta intensidade; Imagens de lesões esportivas.

\section{RESUMEN}

Introducción: Cuando los deportistas realizan entrenamientos deportivos, muchos movimientos son de alta intensidad, y ese entrenamiento es repetitivo, lo que genera desgaste en algunas partes lesionadas. Objetivo: Los deportistas pueden dañar partes del cuerpo en el ejercicio de alta intensidad. Durante el procesamiento, es necesario identificar y analizar las partes dañadas en la imagen. Sin embargo, los métodos relevantes actuales tienen baja precisión y diferentes problemas de eficiencia y calidad. Métodos: En este artículo, se propone un algoritmo Fish Swarm para identificar imágenes de daño por movimiento de alta intensidad. Según la combinación de umbral adaptativo y morfología matemática, se extrae el contorno de la parte dañada de la imagen. Resultados: el método mencionado anteriormente puede mejorar la precisión de la identificación de las partes dañadas de las imágenes de lesiones deportivas, acortar el tiempo de reconocimiento y tiene cierta viabilidad para determinar las partes de las lesiones deportivas. Conclusiones: este método puede ser ampliamente utilizado en lesiones deportivas de alta intensidad. Nivel de evidencia Il; Estudios terapéuticos-investigación de los resultados del tratamiento.

Descriptores: Simulación; Método de reconocimiento; Partes dañadas de alta intensidad; Imágenes de lesiones deportivas. 


\section{INTRODUCTION}

My country has always admired sports, and therefore has achieved many brilliant achievements in sports. But behind the glory is the continuous updating of athletes. Sports athletes are young, and the training costs they pay are usually relatively large. For example, diving athletes, whose competitive skills can be maintained for a relatively short period of time, athletes jump from a relatively high table, perform difficult movements in the air, and finally fall into the water. During the whole process, athletes' body parts are vulnerable to damage. When athletes are performing sports training, many movements are high-intensity movements, and the training subjects are repetitive, resulting in repeated wear and tear on some injured parts. In summary, a method for identifying damaged parts of high-intensity sports injury images is necessary for repairing damaged parts and treating injuries. Detecting and identifying damage and damage has always been the focus of research in various fields. The following results are used as examples to analyze related methods. ${ }^{1}$

Aiming at the problem of low recognition accuracy and low recognition efficiency, a high intensity motion damage image partial recognition method based on fish swarm algorithm is proposed.

\section{METHODS}

\section{Sports injury image processing}

The grayscale conversion operation is performed on the motion-damaged image. For the color motion-damaged image, each pixel contained in it can be characterized by 3 bytes, and each byte corresponds to the brightness generated by the three components $R$, $G$, and $B$, respectively. Assuming that the $R, G$, and $B$ components are different, it is a color image. Assuming that the $R, G$, and $B$ components are the same, it is a grayscale image. Equation (1) is the grayscale value conversion formula

$$
\operatorname{Gray}(i, j)=0.299 \times R(i, j)+0.587 \times G(i, j)+0.114 \times B(i, j)
$$

The grayscale image after conversion by equation (1) is still characterized by a 24-bit image.2

\section{Contour extraction and preliminary recognition of damaged parts of sports injury images}

In order to improve the recognition effect of the damaged part in the motion damage image, it is necessary to extract the contour of the damaged part. The discrete points are fitted by curve fitting method, and the fracture contour is obtained. ${ }^{3}$

The damaged active contour model is a serpentine model, which can be deformed by snake point motion. Use internal forces to smooth the active contour and topology. Assuming that the snake point is in equilibrium, where the corresponding energy is minimal, then the active contour will converge to the edge of the damaged part. Equation (2) is the expression of contour energy

$$
E(C)=\left[\alpha E_{\text {in }}(C)+\beta E_{\text {ex }}(C)\right] \operatorname{Gray}(i, j)
$$

In equation (2), $E(C)$ represents the damage contour energy, $E_{\text {in }}(C)$ represents the internal energy, $E_{e x}(C)$ represents the external energy, and $\alpha$ and $\beta$ represent the weighted values, which can affect the size of the internal energy value and the external energy value.
After extracting the damage contour according to equation (2), the $\mathrm{K}-\mathrm{L}$ transform analysis method is used to realize the initial recognition of the damaged part of the sports injury image.

In order to improve the recognition accuracy of damaged parts, the damage images are arranged as a feature vector with a length of 64 according to the series connection mode, then there is $X=\left\{x_{1}, x_{2}, \mathrm{~L}, x_{m}\right\}$ , where $m$ represents the number of sports damage images.

According to the above, calculate the image mean vector

$$
\mu=\frac{1}{m} \sum_{i=1}^{m} x_{i} \cdot E(C)
$$

In equation (3), $\mu$ represents the overall mean vector of the image.

Set a matrix $A=\left[x_{1}-\mu, x_{2}-\mu, \mathrm{L}, x_{m}-\mu\right]$, covariance matrix, and eigenvalues of $C^{\prime}$ and $A$, arrange the eigenvalues according to the decreasing form, extract the vectors corresponding to the first J non-zero eigenvalues, and calculate the eigenvector of the covariance matrix through equation (4). For the purpose of preserving most of the information of the damaged image, the first $60 \%$ feature values are selected.

$$
\mu_{i}=A \frac{1}{\sqrt{\lambda_{i}}} X \cdot v_{i} \cdot \mu
$$

In equation (4), $\mu_{i}$ represents the eigenvalue of the covariance matrix, $\lambda_{i}$ represents the nonzero eigenvalue of the matrix, and $v_{i}$ represents the vector corresponding to the nonzero eigenvalue. Project all the training samples and the sample of the sports injury image to be identified into the eigenspace $U$, and calculate the projection coefficient:

$$
y_{i}=U^{T} \cdot \mu_{i}
$$

samples were incorporated into equation (6) calculations. the minimum distance of the training samples was the initial recognition result of the image samples to be identified.

$$
d(x, y)=\left[\sum_{i=1}^{n}\left(x_{i}-y_{i}\right)^{2}\right]^{1 / 2}
$$

In equation (6), $d(x, y)$ represents the Euclidean distance between the image sample to be recognized and the training sample, and $n$ represents the number of training samples.

Pixel calculation of damaged parts of damaged images based on fish school.

The cluster center set is selected as the recognition result pattern, and each fish represents a vector of all the cluster center points, while the state of each position of the fish is an arbitrary pixel in the motion damage image. The target function of the fish can be represented as (7)

$$
J_{g}=\sum_{i=1}^{g}\left\|V_{i}-x_{k}\right\|^{2} \cdot d(x, y)
$$

In equation (7), $g$ represents the number of pixel clustering centers, $V_{i}$ represents the pixel clustering center, and $x_{k}$ represents the clustering object. The minimum value of $J_{g}$ is the optimal clustering point, namely $\min J_{g}$, which is used as the basis of image segmentation to realize the damage image segmentation. 
After the gray-scale pixel values of the image are clustered, the clustering results corresponding to the original image pixels are obtained. The clustering results are used to realize the color rendering of the original image pixel class, so that each clustering region in the entire image can represent different colors. The average value obtained by dividing the accumulated value of each type of pixel value RGB flux and the total number of pixels is taken as the representative value of this type of pixel RGB.

Combined with the above analysis, calculate the relative proportional area of the damaged image

$$
\text { Area }_{\text {total }}=\left(\frac{W^{\prime}}{D^{\prime}}\right) \cdot 2.54 \cdot\left(\frac{H^{\prime}}{D^{\prime}}\right) \cdot 2.54
$$

In equation (8), Area $_{\text {total }}$ represents the relative proportional area of the damaged image, $W^{\prime}, H^{\prime}$ represents the number of pixels in the horizontal and vertical directions of the damaged image, and $D^{\prime}$ represents the image resolution. After clustering and segmentation of the original image, the area of the damaged area of the damaged image can be obtained according to the proportion of the total number of such pixels in the total number of pixels of the image

$$
\text { Area }_{i}=\frac{P}{P^{\prime}} \cdot \text { Area }_{\text {total }} \cdot \min J_{g}
$$

In Equation (9), Area $_{i}$ represents the pixel area of the damaged part obtained by segmentation, $P$ represents the total number of pixels in the damaged part, and $P^{\prime}$ represents the total number of pixels in the image.

In order to verify the overall performance of the high-intensity motion damage image recognition method based on the fish swarm algorithm, the experimental platform was built on an 17-4770 eight-core processor, 4G memory, and 2G memory environment. The experimental data comes from a city sports institute, and 100 athletes are selected. Table 1 shows the details of the experimental objects.

Using relevant instruments to carry out data collection on each body part of the test subject, the obtained partial image example is shown in Figure 1 through perspective.

Table 1. Details of experimental objects.

\begin{tabular}{c|c}
\hline project & Remarks \\
\hline male & 55 \\
\hline female & 45 \\
\hline Height range/cm & $162-183$ \\
\hline Weight range/kg & $44-75$ \\
\hline Training program & $\begin{array}{c}\text { Weightlifting, sprinting, long-distance running, long jump, high } \\
\text { jump, shot put, basketball, football, table tennis, javelin, etc. }\end{array}$ \\
\hline
\end{tabular}

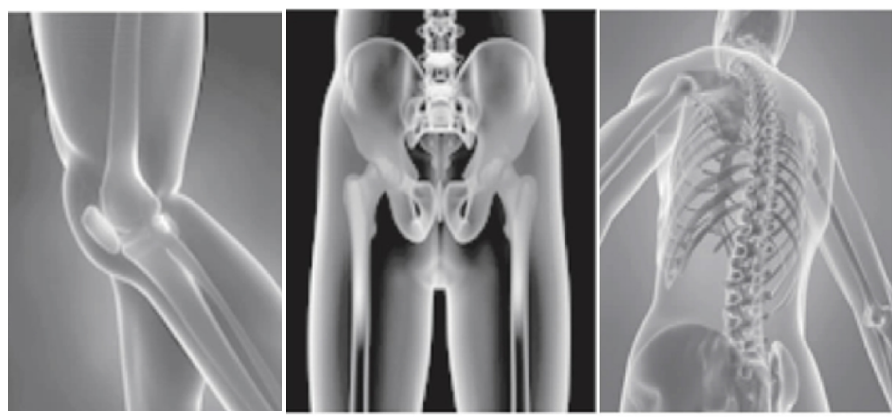

Figure 1. Example of experimental data.
According to the above experimental environment and experimental data, the identification method of high-intensity sports injury image broken parts based on fish swarm algorithm was verified with the following indicators: 1) Recognition rate. 2) Identification takes time.

\section{RESULTS}

Analysis of Figure 2 shows that the recognition rate curve of the damage detection method based on linear discrimination and ultrasonic image features has an inverted U-shaped development, and the overall recognition rate is low; the damage extraction method based on improved spectral clustering has a large fluctuation in the recognition rate curve, indicating that this The method has poor feasibility; the recognition rate of high-intensity sports injury image damage location recognition method based on fish swarm algorithm is significantly higher than the traditional method. This method lays the foundation for the identification of damaged parts by extracting the outline of the damaged parts of the sports injury image, and uses the K-L transform analysis method to achieve the initial recognition of the damaged parts of the sports injury image, which initially improves the recognition accuracy. The fish swarm algorithm is used to give the image segmentation results, so as to obtain the proportion of the damaged pixels occupying the total pixels of the image, which further improves the recognition accuracy. The above experimental results prove that the proposed method has strong practicability and robustness. Figure 3 shows the MRI image of the calf triceps injury. ${ }^{4}$

Among them, the coronal T2WI(1) and axial FS-T2WI(2) showed a "feather"-like long T2 signal exudation between the medial head muscle bundle of the gastrocnemius muscle ( $\boldsymbol{\xi}$ ), and a small length between the adjacent head of the gastrocnemius muscle and the soleus muscle T2 signal effusion $(\triangle)$ graph.

\section{Results of Experiment 2}

It is known from Figure 4 that under different numbers of images to be recognized, the identification method of the damaged part of the high-intensity sports injury image based on the fish swarm algorithm takes the shortest time to identify, indicating that the method has the highest identification efficiency. This method effectively reduces the time-consuming identification by grayscale conversion of the image before identifying the damaged part. As shown in Figure 5, it is a patient with grade II injury of the medial head of the gastrocnemius muscle.

The coronal position FS-T2WI $(3,4)$ shows a partial tear at the junction of the muscle tendon $(\uparrow)$, the muscle stump becomes thin and root-like $(\uparrow)$, the tendon stump loosens (short $\uparrow$ ), around the stump and inside the gastrocnemius muscle A small amount of long T2 signal effusion $(\triangle)$ can be seen between the head and soleus muscles, and a "feather"-like long T2 signal effusion ( $\boldsymbol{\xi}$ ) can be seen between the medial head muscle bundles.

From the experimental results, the proposed method has strong advantages in both recognition rate and recognition efficiency, indicating that the method can provide a strong basis and support for research in this field. ${ }^{5}$

\section{DISCUSSION}

In this study, the damage caused by the inner head of gastrointestitis accounted for $77.3 \%$, due to the longermost head of the inner head and produced a larger tension than the horizontal head, and the lateral head shorter speed is higher than the inner side head.In this study, Soleus muscles injured 29\% of calf triamuscular injury, which significantly below gastrid muscle damage, mainly because Soleus muscles span a joint and rich in l-type slow muscle fibers. The composition ratio of 


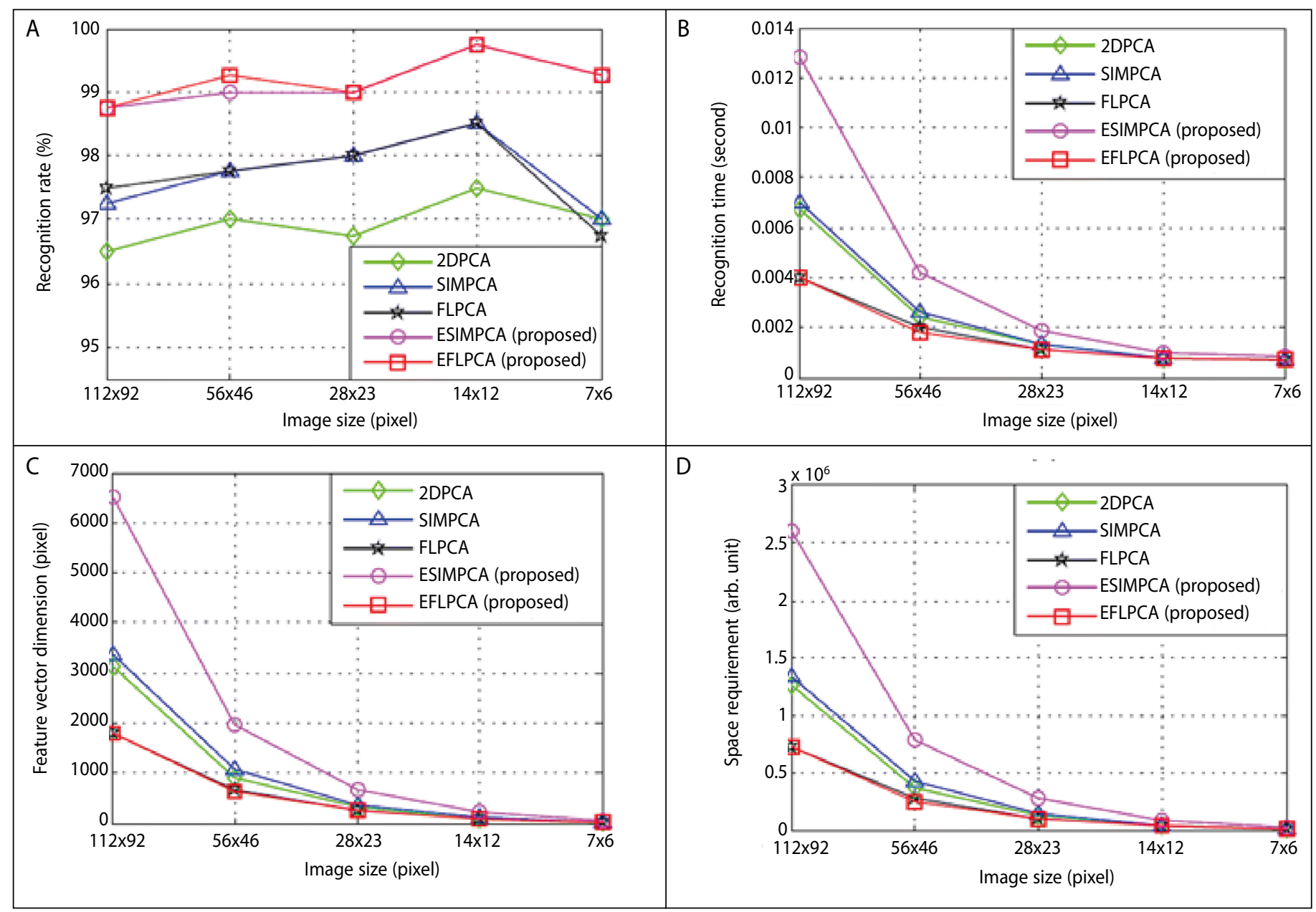

Figure 2. Comparison of recognition rates by different methods.

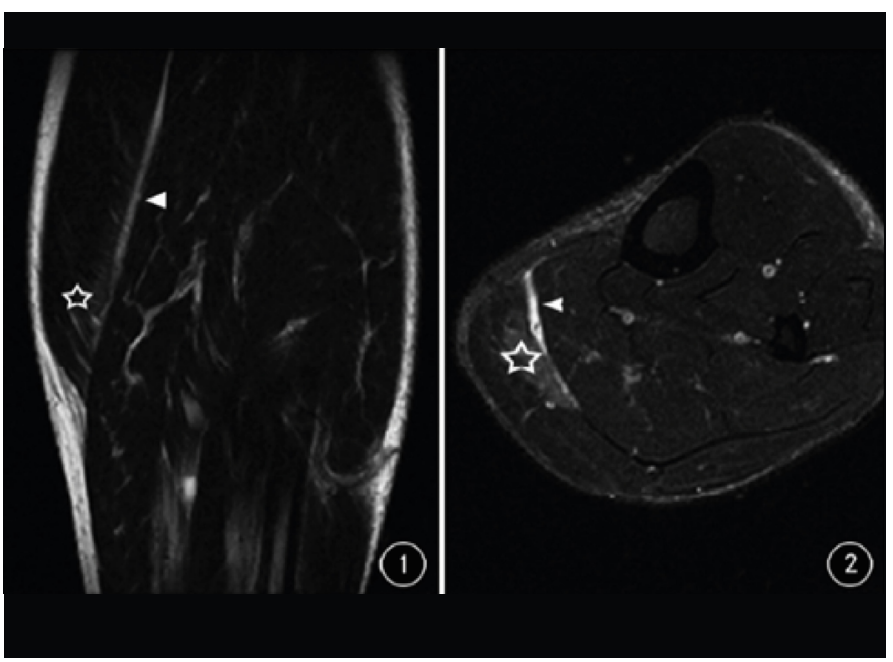

Figure 3. Patients with grade I injury of the medial head of the gastrocnemius muscle.

the two in this study is 3:1, where independent damage in the inner side of the gastrointer muscle is the most common, accounting for more than half of the side, and the lateral head exists in combination damage, and there is no independent injury discovery hurt. In this study, independent and combined injuries of soleus muscles were both visible in 5 and 4 cases, respectively. In terms of the degree of injury, the medial head of gastrocnemius muscle is higher in grade II and III injuries. The lateral head of gastrocnemius muscle and soleus muscle are common in grade I injury. The main reason for the analysis is that the medial head of gastrocnemius muscle is long and the tension is large, so it is damaged. ${ }^{6}$
Depending on the degree of tendon damage, the three-legged three-head muscles damage is divided into I, II and III, which is a simple strain, partial tear and complete rupture. When the level I damage occurs, the injured muscle tendon shape is normal, only the local muscle strain is displayed. Deep-skinned injury is rare in the I grade strain, only 2 cases in this article, accounting for $22.2 \%$. In level II damage, it is more common in local tear of gastrid muscles. The effusion is generally band-shaped or fusiform with long $\mathrm{T} 1$ and long T2 signals. During hemorrhage, the effusion signal on T1Wl is close to the muscle signal or slightly higher. For the muscle signal, a sheet-like or "feather"-like long T2 signal can be seen in the muscle near the broken end, which is a manifestation of exudation between muscle bundles. In grade III injury, the junction of the tendon of the medial head of the gastrocnemius muscle was completely broken, and the muscle and tendon of the broken end were retracted and thickened. The effusion between soleus muscles is also more common and more common than Grade II injuries.

\section{CONCLUSION}

Regarding the prevention of cervical fragments, it is to strengthen the neck resistance to left-turn training; the second is to strengthen the resistance of the neck to the right turn. Regarding the prevention of shoulder damage, athletes must pay attention to the standardization and standardization of exercise during training. At this point, the coach should play a role in corrective movements and minimize damage. About preventing eye damage, it is necessary to improve the awareness of athletes to protect their eyes and correct their irregular movements to minimize damage caused by high intensity motion.

All authors declare no potential conflict of interest related to this article 


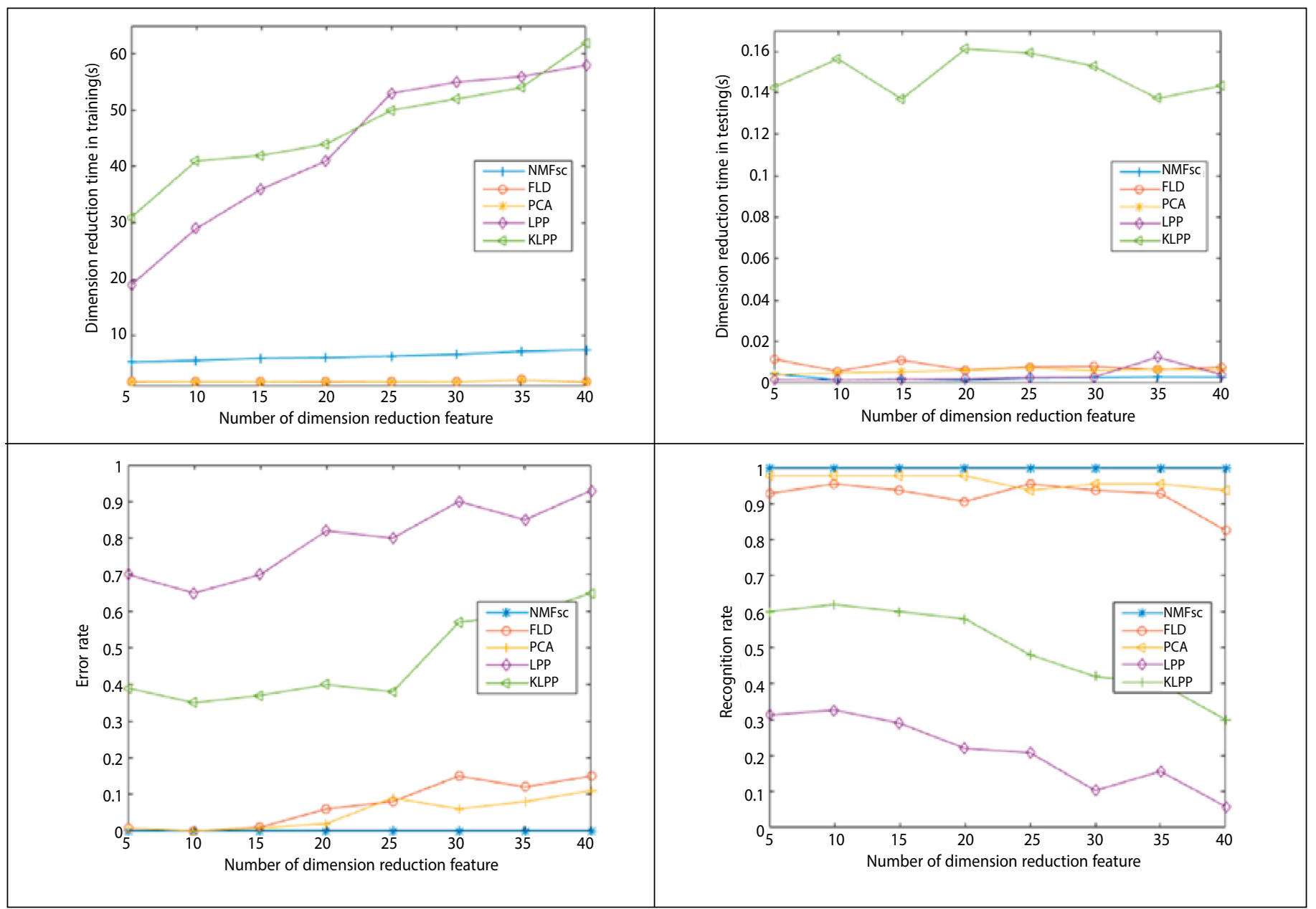

Figure 4. Comparison of time-consuming identification by different methods.
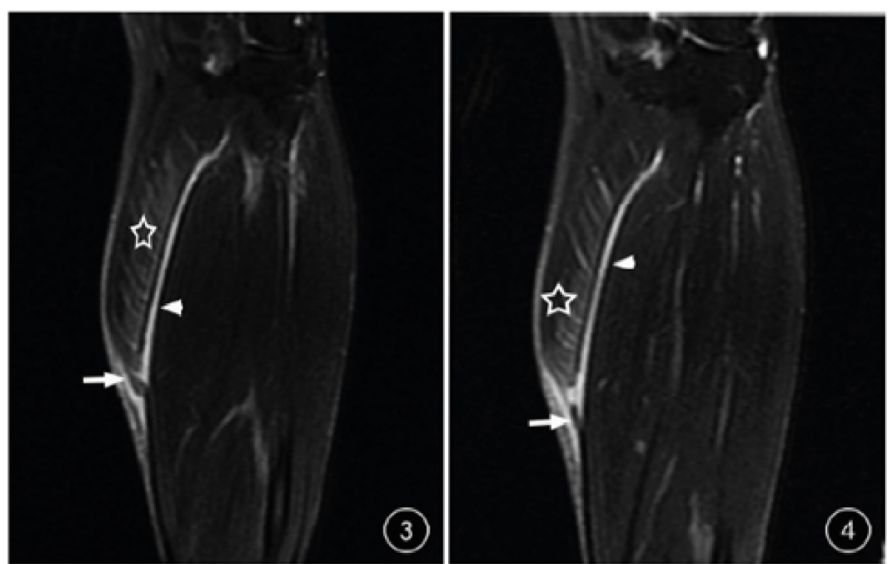

Figure 5. Patients with grade II injury of the medial head of the gastrocnemius muscle.

AUTHORS' CONTRIBUTIONS: Each author made a significant personal contribution to the manuscript. Feng Wang analyzed and explained the data about sports athletes causing certain damage to various parts of the body during high-intensity exercise. For the current poor quality problem, the existing related methods have low recognition accuracy and efficiency, and proposed a high-intensity sports injury image identification method based on fish school algorithm. Fei He performs gray-scale conversion operations on sports injury images, and combines adaptive threshold and mathematical morphology to extract the contours of the injury parts in the image. And is the main contributor to the writing of the manuscript. Final manuscript read and approved by all authors.

\section{REFERENCES}

1. Ramos JS, Dalleck LC, Tjonna AE, Beetham KS, Coombes JS. The impact of high-intensity interval training versus moderate-intensity continuous training on vascular function: a systematic review and meta-analysis. Sports Med. 2015;45(5):679-92

2. Wu S. A Traffic motion object extraction algorithm. International Journal of Bifurcation and Chaos. 2018;25(14):1540039.

3. McIntyre JP, Kilding AE. Effects of high-intensity intermittent priming on physiology and cycling performance. J Sports Sci. 2015;33(6):561-7.
4. Brown DM, Teseo AJ, Bray SR. Effects of autonomous motivational priming on motivation and affective responses towards high-intensity interval training. J Sports Sci. 2016;34(16):1491-9.

5. Wu S, Wang M, Zou Y. Research on internet information mining based on agent algorithm. Future Generation Computer Systems. 2018 [cited 2021 Jun 28];86;598-602. Available from: https://www.x-mol.com/paper/1308586462076440576?recommendPaper=1308336102296489984

6. Schmidt D, Anderson K, Graff M, Strutz V. The effect of high-intensity circuit training on physical fitness. J Sports Med Phys Fitness. 2016;56(5):534-40 